\title{
RHEUMATOID ARTHRITIS AND GOUT IN HIROSHIMA AND NAGASAKI, JAPAN
}

\author{
A PREVALENCE AND INCIDENCE STUDY
}

\author{
Hiroo Kato, * M.D., Ivan F. Duff, $\dagger$ M.D., Walter J. Russell, $\ddagger$ M.D., \\ Yutaka Uda, § M.D., Howard B. Hamilton, $\|$ M.D., Sadahisa Kawamoto, 9 M.D. \\ and KENNETH G. JoHNSON, ** M.D. \\ Atomic Bomb Casualty Commission, Hiroshima, Japan $\nmid \dagger$
}

(Received 18 December 1968; in revised form 29 October 1969; further revised 5 June 1970)

\section{BACKGROUND}

SINCE 1958, the Atomic Bomb Casualty Commission (ABCC) has been conducting a long-term follow-up investigation (Adult Health Study) [1] of large defined population samples in Hiroshima and Nagasaki, Japan. In the course of this program the prevalence of definite rheumatoid arthritis was measured and its incidence estimated, according to observations made upon 16,269 subjects from 1958 to 1964 [2].

The original observations were made during routine medical examinations, not specifically designed to detect rheumatoid arthritis, and with the inherent disadvantages of a retrospective approach. A prospective rheumatic disease study was therefore conducted at $\mathrm{ABCC}$ from 1965 to 1967 for the specific detection of rheumatic diseases and to determine age-sex specific prevalence and the incidence of rheumatoid arthritis. It was also intended (1) to define the natural history of rheumatoid arthritis as related to physical and environmental factors; (2) to detect any relationship between A-bomb radiation exposure and the disease; (3) to define the

*Department of Statistics.

†Professor of Internal Medicine, in charge of the Rackham Arthritis Research Unit, University of Michigan. Dr. Duff participated in these studies during an off-campus leave, supported by a Commonwealth Foundation Fellowship and the Horace H. Rackham School of Graduate Studies, University of Michigan.

$\ddagger$ Chief, Department of Radiology.

\$Department of Radiology.

IIChief, Clinical Laboratories.

TDepartment of Medicine.

**Former Chief, Department of Medicine. Present address: Director, Division of Epidemiologic Research, Cornell University Medical College, Department of Public Health, New York.

t†A co-operative Research Agency of U.S.A. National Academy of Sciences-National Research Council and the Japanese National Institute of Health and Welfare, with funds provided by the U.S.A. Atomic Energy Commission, the Japanese National Institute of Health, and the U.S. Public Health Service. 
distribution characteristics of serum uric acid values and the age-sex specific prevalence rates of 'probable' gout; and (4) to evaluate screening methods used. Methodology similar to that of the Tecumseh Community Health Survey [3] conducted by the University of Michigan was used to facilitate comparison of the two populations.

\section{METHODS}

The Adult Health Study (AHS), the major medical program at ABCC, includes biennial examinations of members of a representative group of atomic bomb survivors and suitable comparisons. It is a unique, large-scale epidemiological study originally of 20,000, now of approximately 18,000 subjects, as follows:

Group I: Exposed within $2000 \mathrm{~m}$ of the hypocenter and experienced acute radiation symptoms (epilation, bleeding or oropharyngeal lesions).

Group II: Exposed within $2000 \mathrm{~m}$ of the hypocenter, but did not experience acute radiation symptoms.

Group III: Exposed between 3000 and $3499 \mathrm{~m}$ from the hypocenter in Hiroshima and between 3000 and $3999 \mathrm{~m}$ in Nagasaki.

Group IV: Located beyond $10,000 \mathrm{~m}$ from the hypocenter or not in the city at the time of the bomb.

Groups II, III and IV are age- and sex-matched to Group I.

Details of the Adult Health Study sample, its general clinic procedures and methodology, have been described elsewhere [1]. The present report concerns 21 months from April, 1965 through December 31, 1966 during which 9978 Hiroshima individuals and 4812 in Nagasaki were scheduled for examination. Since subjects who moved out of the cities before their scheduled examinations could not be included, the examination rate, based on all subjects residing within the cities and adjacent area, was 87 per cent. There was no significant difference in the examination rate by sex and city. The number of subjects actually examined was 7905 (2784 male, 5121 female) in Hiroshima and 3488 (1409 male, 2079 female) in Nagasaki.

Complete medical, family, dietary and radiation histories were obtained, and detailed physical examinations were performed on all subjects in the ABCC clinic. Those unable to visit the clinic were interviewed and examined at home. All data were recorded by one, and reviewed by a second physician.

Specific information about nodules, morning stiffness, joint pain, tenderness, heat, erythema, swelling, limitation of motion, and/or deformity were recorded and supplemented by answers to the following questions:

1. Have you ever at any time had arthritis or rheumatism?

2. Have you ever had pain or aching of your joints?

3. Have you ever had swelling of your joints?

4. Do you wake up with stiffness or aching of your joints?

Laboratory examinations included a complete blood count, blood sugar, serum cholesterol, serum protein, cardiolipin test for syphilis, and urinalysis. Rheumatoid factors were determined initially by the rapid slide test (Hyland), and a positive slide test was checked by the Singer and Plotz tube dilution latex fixation test [4]. The tubes were read after overnight incubation at $5^{\circ} \mathrm{C}$. Agglutination in a dilution of $1: 160$ or greater was regarded as positive. Serum uric acid levels were determined by automated analysis (Technicon Auto Analyzer, method N-13a). Samples of serum were exchanged between the laboratories of the Rackham Arthritis Research Unit and ABCC 
to compare rheumatoid factor detection and measurement of serum uric acid content.

Subjects who replied 'yes' to questions 2, 3 and 4 of the questionnaire and/or had latex fixation titer of 1:160 or greater were recalled for posteroanterior (PA) hand and wrist roentgenograms. Also those whose physical findings alone suggested rheumatoid arthritis were radiographed. All roentgenograms were independently interpreted by three of us (I.D., Y.U., W.R.) using Kellgren's criteria for classification of rheumatoid arthritis [5]. Any lack of agreement was resolved by conference readings.

Diagnoses were made according to the International Classification of Diseases. This did not allow categorizing rheumatoid arthritis as classic, definite, probable or possible. Therefore, medical records of all cases with diagnoses of any kind of joint disease, including rheumatoid arthritis, gout or osteoarthritis were reviewed by one of us (I.D.). Records of all subjects with positive replies to the questionnaire, and/or a positive Singer and Plotz rheumatoid factor test, and those recalled for radiographs, were similarly reviewed. Diagnoses of rheumatoid arthritis were made according to criteria of the American Rheumatism Association [6], and classified as definite, probable, or possible. Classical rheumatoid arthritis was inclued in the definite group. To these groups a questionable category was added. This system of grading is similar to that of the Tecumseh Study. It avoids exclusion from future evaluations of individuals with only joint pain, tenderness, morning stiffness, joint swelling, or a positive latex fixation test. Classification was specifically for the examination at which the diagnosis was established.

To verify diagnoses, 42 selected individuals in Hiroshima, and 40 in Nagasaki, usually from the probable or possible category, were recalled for examination by one of us (I.D.). Home visits were made when patients could not come to the clinics. Good agreement between chart review and reexamination by the rheumatologist attest to the accuracy of the previously recorded observations. Most of these subjects by now have had several examinations. We are reasonably confident the diagnosis of definite rheumatoid arthritis would not, by now, have been missed.

Subjects with definite, probable, possible, or questionable rheumatoid arthritis are shown in Table 1. Further analysis in this report will be limited to the 63 individuals with definite rheumatoid arthritis.

\section{Prevalence}

\section{RESULTS}

The prevalence rate of definite rheumatoid arthritis in both cities during the survey period was 0.4 for males and 0.7 per cent for females (Table 2). The combined preva-

TABLE 1. RHEUMATOID ARTHRITIS BY CITY, SEX AND DIAGNOSTIC ClasS

\begin{tabular}{lccccc}
\hline \multirow{2}{*}{ City } & Sex & \multicolumn{5}{c}{ Rheumatoid arthritis } \\
\cline { 3 - 6 } & & Definite & Probable & Possible & Questionable \\
\hline Hiroshima & M & 13 & 2 & 6 & 31 \\
& F & 32 & 10 & 32 & 89 \\
Nagasaki & Total & 45 & 12 & 38 & 120 \\
& M & 3 & 1 & 10 & 35 \\
& F & 15 & 10 & 19 & 94 \\
& Total & 18 & 11 & 29 & 129 \\
\hline
\end{tabular}


Table 2. Prevalence of Rheumatoid arthrits by age, Sex, city, Defintte cases only

\begin{tabular}{|c|c|c|c|c|c|c|c|c|c|c|}
\hline \multirow{2}{*}{ Sex } & \multirow{2}{*}{$\begin{array}{l}\text { Age at } \\
\text { exam. }\end{array}$} & \multicolumn{3}{|c|}{ Hiroshima } & \multicolumn{3}{|c|}{ Nagasaki } & \multicolumn{3}{|c|}{ Hiroshima + Nagasaki } \\
\hline & & RA & $\begin{array}{l}\text { Popula- } \\
\text { tion }\end{array}$ & $\begin{array}{l}\text { Preva- } \\
\text { lence } \\
(\%)\end{array}$ & RA & $\begin{array}{l}\text { Popula- } \\
\text { tion }\end{array}$ & $\begin{array}{l}\text { Preva- } \\
\text { lence } \\
(\%)\end{array}$ & RA & $\begin{array}{c}\text { Popula- } \\
\text { tion }\end{array}$ & $\begin{array}{c}\text { Preva- } \\
\text { lence } \\
(\%)\end{array}$ \\
\hline $\mathbf{M}$ & $\begin{array}{c}\text { All ages } \\
<30 \\
30- \\
40- \\
50- \\
60- \\
70+\end{array}$ & $\begin{array}{r}13 \\
0 \\
1 \\
0 \\
1 \\
9 \\
2\end{array}$ & $\begin{array}{r}2784 \\
211 \\
704 \\
363 \\
559 \\
639 \\
308\end{array}$ & $\begin{array}{l}0.5 \\
\overline{0.1} \\
\overline{0.2} \\
1.4 \\
0.6\end{array}$ & $\begin{array}{l}3 \\
0 \\
0 \\
0 \\
0 \\
3 \\
0\end{array}$ & $\begin{array}{r}1409 \\
162 \\
430 \\
209 \\
287 \\
254 \\
67\end{array}$ & $\begin{array}{l}0.2 \\
= \\
= \\
1.2 \\
-\end{array}$ & $\begin{array}{r}16 \\
0 \\
1 \\
0 \\
1 \\
12 \\
2\end{array}$ & $\begin{array}{r}4193 \\
373 \\
1134 \\
572 \\
846 \\
893 \\
375\end{array}$ & $\begin{array}{l}0.4 \\
\overline{0.1} \\
\overline{0.1} \\
1.3 \\
0.5\end{array}$ \\
\hline F & $\begin{array}{c}\text { All ages } \\
<30 \\
30- \\
40- \\
50- \\
60- \\
70+\end{array}$ & $\begin{array}{r}32 \\
2 \\
0 \\
4 \\
7 \\
14 \\
5\end{array}$ & $\begin{array}{r}5121 \\
326 \\
1099 \\
1183 \\
1062 \\
1035 \\
416\end{array}$ & $\begin{array}{l}0.6 \\
0.6 \\
\\
0.3 \\
0.7 \\
1.4 \\
1.2\end{array}$ & $\begin{array}{r}15 \\
0 \\
0 \\
5 \\
3 \\
4 \\
3\end{array}$ & $\begin{array}{r}2079 \\
199 \\
775 \\
521 \\
280 \\
219 \\
85\end{array}$ & $\begin{array}{l}0.7 \\
- \\
1.0 \\
1.1 \\
1.8 \\
3.5\end{array}$ & $\begin{array}{r}47 \\
2 \\
0 \\
9 \\
10 \\
18 \\
8\end{array}$ & $\begin{array}{r}7200 \\
525 \\
1874 \\
1704 \\
1342 \\
1254 \\
501\end{array}$ & $\begin{array}{l}0.7 \\
0.4 \\
\\
0.5 \\
0.7 \\
1.4 \\
1.6\end{array}$ \\
\hline
\end{tabular}

lence rate for both cities and sexes was 0.55 per cent. The expected increment with age was observed; prevalence rates among women were higher than among men in both cities. No consistent difference was observed in the prevalence rates between Hiroshima and Nagasaki.

To determine the relationship of prevalence of definite rheumatoid arthritis to radiation exposure, subjects were divided into the following four groups: $<1400 \mathrm{~m}$ from the hypocenter, 1400-1999 m, 3000-3999 m, and not in the city at the time of the bombs. The median radiation dose was calculated from recently revised estimates [7] for each exposure group is as follows:

\begin{tabular}{ccc}
\hline $\begin{array}{c}\text { Distance group } \\
(\mathrm{m})\end{array}$ & $\begin{array}{c}\text { Hiroshima } \\
\text { (rad.) }\end{array}$ & $\begin{array}{c}\text { Nagasaki } \\
\text { (rad.) }\end{array}$ \\
\hline$<1400$ & 118 & 238 \\
$1400-1999$ & 15 & 68 \\
$3000+$ & 0 & 0 \\
\hline
\end{tabular}

No consistent differences were observed in prevalence by radiation exposure groups regardless of the manner of combining the different city-sex categories or the distance at which the division was made (Table 3 ).

\section{Incidence}

Prevalence data previously reported [2] for definite rheumatoid arthritis in this sample from 1958-64 was based on examinations by numerous physicians and routine clinical and laboratory tests not specifically designed to detect arthritis. Accurate determination of incidence of rheumatoid arthritis presupposes a defined population with systematic screening of subjects at each examination. This population is fixed unlike that of Tecumseh, and AHS Examinations are standardized. Prevalence rates for the 1958-64 period [2] were in accord with those of other studies. Thus our 


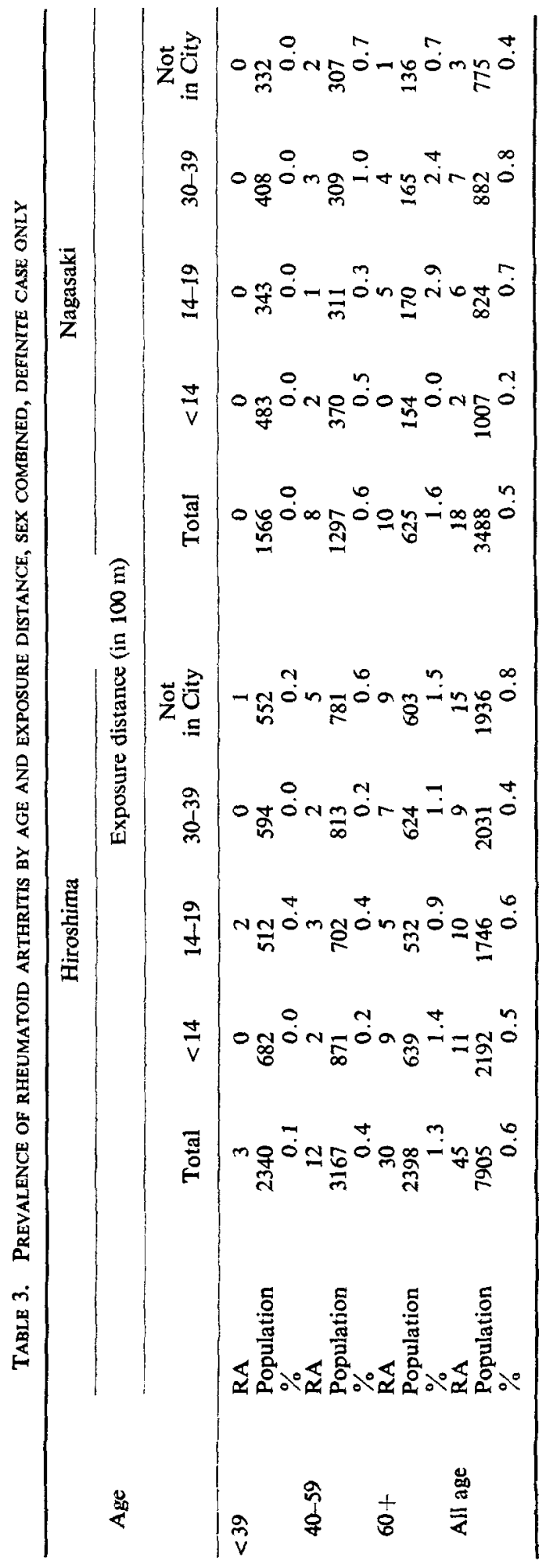




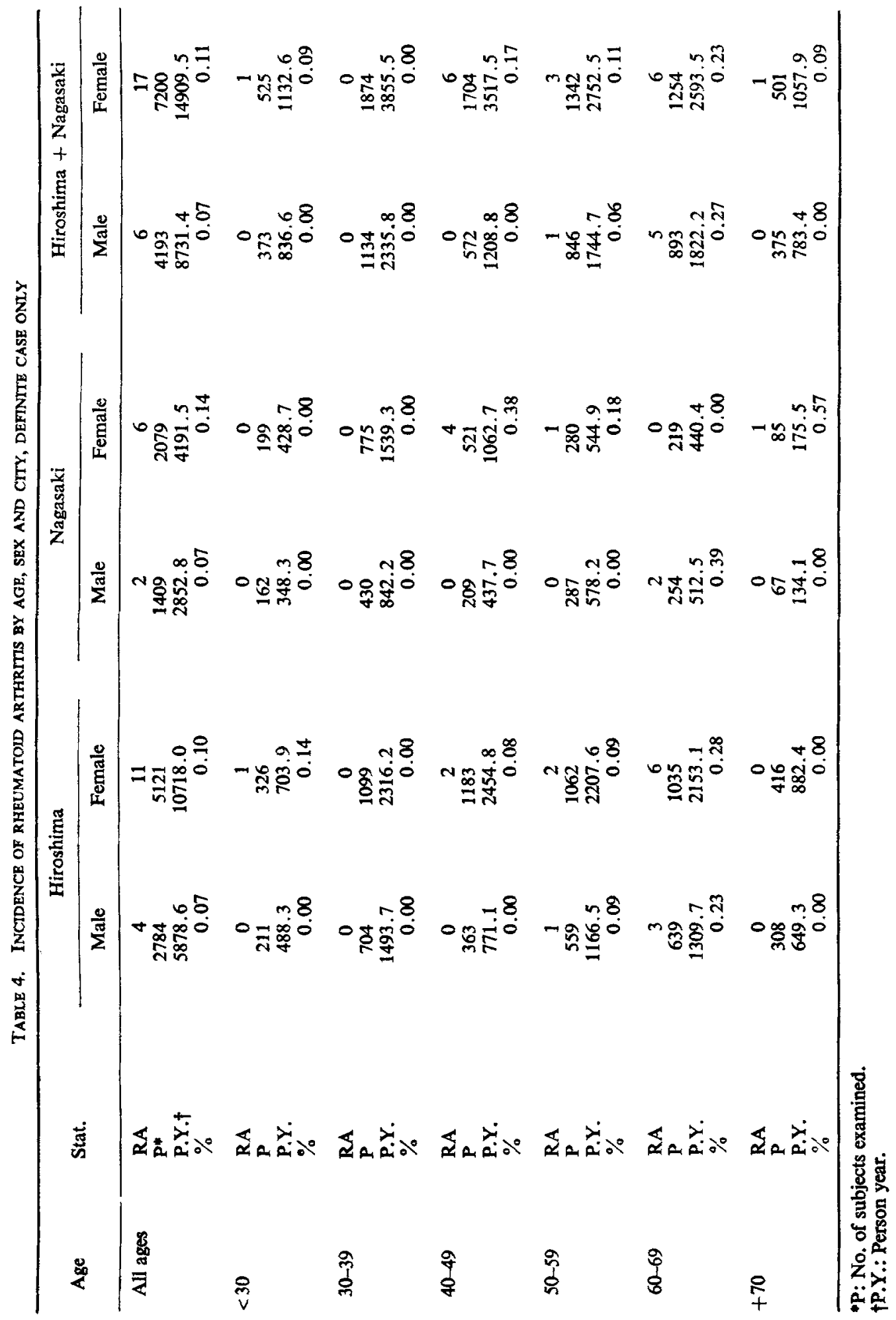


prospective studies provided good opportunities to estimate the incidence of rheumatoid arthritis in this population.

Date of onset of definite rheumatoid arthritis was established to determine incidence according to those in whom onset occurred after previous examinations (1958-64). Since the periods from the previous to the current examinations varied by individual subjects, durations of observations were expressed in person-months and were then reduced to person-year in the final analysis for denominators in calculating incidence.

The incidence rates were 0.07 and 0.11 per cent per year for men and women respectively in Hiroshima and Nagasaki (Table 4), and 0.097 per cent for cities and sexes combined. As with prevalence, the incidence rate increased with age and was higher for females than males.

\section{Questionnaire and rheumatoid arthritis}

The frequency of affirmative replies to the four screening questions for rheumatoid arthritis by sex and city is shown in Table 5. Positive rates did not differ by city; they were consistently higher for women, and increased with age as did the difference between men and women (Fig. 1).

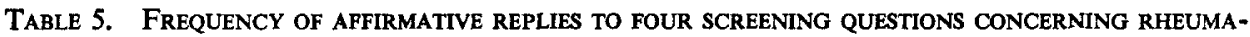
toID ARTHRITIS BY SEX, Hiroshima, NAGasaki aND TeCUMSEH

\begin{tabular}{|c|c|c|c|c|c|c|c|}
\hline & \multirow{2}{*}{ Question } & \multicolumn{2}{|c|}{ Hiroshima (\%) } & \multicolumn{2}{|c|}{ Nagasaki (\%) } & \multicolumn{2}{|c|}{ Tecumseh* $(\%)$} \\
\hline & & $\mathbf{M}$ & $\mathbf{F}$ & $\mathbf{M}$ & F & $\mathbf{M}$ & F \\
\hline 1. & Ever had arthritis or rheumatism & 7.3 & 15.3 & 7.0 & 15.8 & $\begin{array}{c}13.3 \\
(25.0)\end{array}$ & $\begin{array}{c}19.2 \\
(34.6)\end{array}$ \\
\hline 2. & Pain or aching in joints & 21.1 & 32.4 & 16.8 & 27.3 & $\begin{array}{c}34.4 \\
(47.3)\end{array}$ & $\begin{array}{c}34.8 \\
(51.0)\end{array}$ \\
\hline 3. & Joint swelling & 6.8 & 13.2 & 6.1 & 11.2 & $\begin{array}{c}13.4 \\
(24.3)\end{array}$ & $\begin{array}{c}16.9 \\
(32.5)\end{array}$ \\
\hline & Morning stiffness & 8.8 & 13.5 & 7.0 & 9.6 & $\begin{array}{c}15.7 \\
(24.5)\end{array}$ & $\begin{array}{c}19.5 \\
(31.0)\end{array}$ \\
\hline
\end{tabular}

*Numbers in parenthesis are age adusted rates using Hiroshima and Nagasaki combined population as standard.

Positive replies to questions 1,3 , and 4 composed a positive 'rheumatoid arthritis' index, as defined by Cobb et al $[8,9]$. The age and sex specific prevalence of the positive rheumatoid arthritis index is shown in Table 6. Of the 11,167 respondents in both cities, 464 (4.2 per cent) answered yes to the three questions. The prevalence of positive indices for women in each city was more than twice that of males. In both cities it increased with age; no difference between cities was observed. In 76 per cent (353) of 464 individuals with a positive index, there was no other clinical reason to suspect rheumatoid arthritis. Of 61 subjects who had definite rheumatoid arthritis, 78.7 per cent had a positive index (Table 7). These findings are similar to those of the Tecumseh Community Health Study.

\section{Environmental factors in relation to rheumatoid arthritis}

Distributions of 20 environmental factors for persons with and without rheumatoid arthritis were compared. These included: marital status and number of children, education, usual occupation, smoking history, use of alcoholic beverages, frequency 


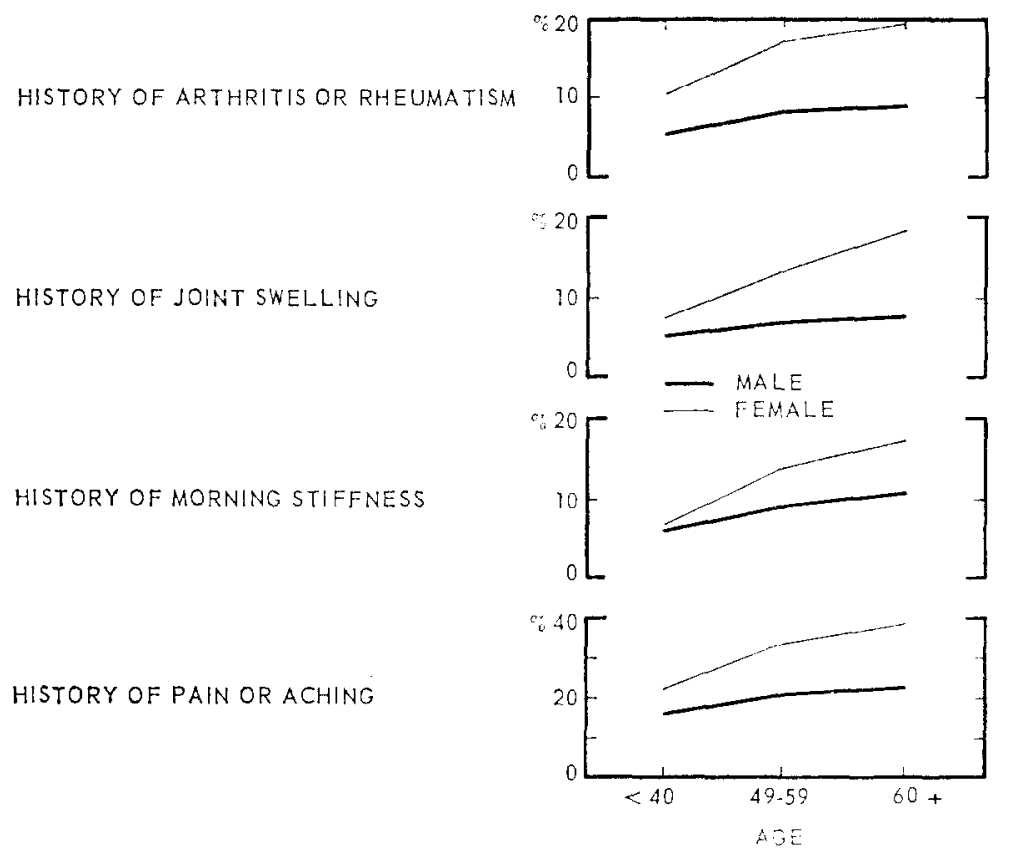

FIg. 1. Prevalence of positive replies to the four related questions, Hiroshima and Nagasaki combined.

TABle 6. Proportion of Rheumatoid arthritis indeX* POSITIVE CASES by AGE, SEX AND CITY

\begin{tabular}{|c|c|c|c|c|c|c|c|}
\hline \multirow{2}{*}{ Sex } & \multirow{2}{*}{ Age } & \multicolumn{3}{|c|}{ Hiroshima } & \multicolumn{3}{|c|}{ Nagasaki } \\
\hline & & $\begin{array}{l}\text { No. of } \\
\text { positive }\end{array}$ & $\begin{array}{l}\text { Total No. of } \\
\text { respondents }\end{array}$ & $\%$ & $\begin{array}{r}\text { No. of } \\
\text { positive }\end{array}$ & $\begin{array}{l}\text { Total No. of } \\
\text { respondents }\end{array}$ & $\%$ \\
\hline \multirow{7}{*}{ Male } & All ages & 56 & 2725 & 2.1 & 23 & 1367 & 1.7 \\
\hline & $<30$ & 0 & 210 & - & 1 & 160 & 0.6 \\
\hline & 30 & 10 & 698 & 1.4 & 6 & 429 & 1.4 \\
\hline & $40-$ & 7 & 359 & 1.9 & 6 & 205 & 2.9 \\
\hline & 50 & 10 & 548 & 1.8 & 7 & 282 & 2.5 \\
\hline & 60 & 19 & 617 & 3.1 & 3 & 238 & 1.3 \\
\hline & $70+$ & 10 & 293 & 3.4 & 0 & 53 & - \\
\hline \multirow{7}{*}{ Female } & All ages & 296 & 5056 & 5.9 & 89 & 2019 & 4.4 \\
\hline & $<30$ & 4 & 324 & 1.2 & 2 & 196 & 1.0 \\
\hline & 30 & 35 & 1087 & 3.2 & 20 & 759 & 2.6 \\
\hline & 40 & 49 & 1173 & 4.2 & 19 & 509 & 3.7 \\
\hline & 50 & 86 & 1052 & 8.2 & 23 & 271 & 8.5 \\
\hline & 60 & 80 & 1020 & 7.8 & 18 & 208 & 8.7 \\
\hline & $70+$ & 42 & 400 & 10.5 & 7 & 76 & 9.2 \\
\hline
\end{tabular}

*A positive index is defined as an affirmative response to question 1,3 and 4 (p6).

of food intake such as rice, bread, fish, meat, ham, milk, butter, eggs, 'miso' soup, bean cake, sea weed, coffee, cake and fruit. Since the distribution of individuals with rheumatoid arthritis was shifted to higher ages as compared to those without rheumatoid arthritis, an age adjustment based on age specific distribution at 10 year intervals was performed for this comparison. No statistically significant difference was observed in the distribution of these environmental factors among those with or without rheumatoid arthritis. For example, the age-adjusted distribution of men by 
TABLE 7. THE ASSOCIATION BETWEEN POSITIVE RHEUMATOID ARTHRITIS INDEX AND CLINICAL DIAGNOSIS OF RHEUMATOID aRTHRITIS, Hiroshima, NAGASAKI, BOTH SEX AND ALL AGES COMBINED

\begin{tabular}{lccc}
\hline & \multicolumn{2}{c}{ RA index } & Total \\
\cline { 2 - 4 } $\begin{array}{l}\text { Diagnosis of } \\
\text { rheumatoid arthritis }\end{array}$ & Positive & Negative & \\
\hline Definite rheumatoid arthritis & $a$ & $b$ & $a+b$ \\
& 48 & 13 & 61 \\
$\begin{array}{l}\text { Not definite } \\
\text { rheumatoid arthritis }\end{array}$ & $c$ & $d$ & $c+d$ \\
\hline \multicolumn{1}{c}{ Total } & 416 & 10690 & 11106 \\
\hline & $a+c$ & $b+d$ & $a+b+c+d$ \\
& 464 & 10703 & 111617
\end{tabular}

Sensitivity of RA index $=\frac{a}{a+b}=\frac{48}{61}=78.7$ per cent

Specificity of RA index $=\frac{d}{c+d}=\frac{10690}{11106}=96.3$ per cent

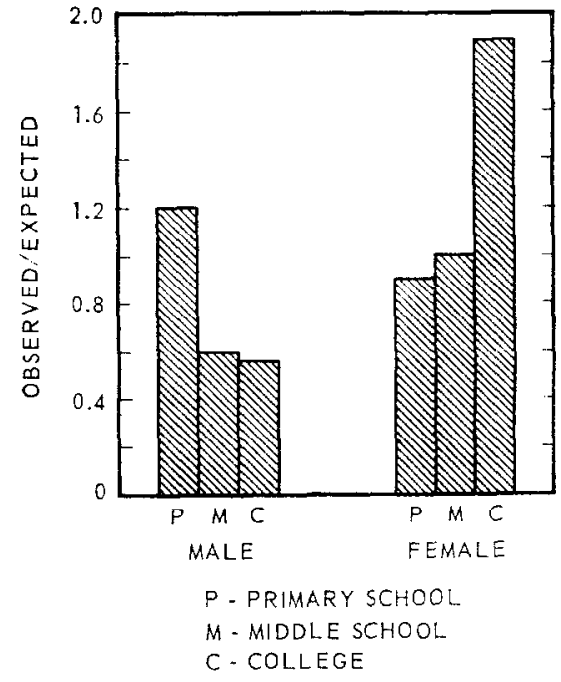

FIG. 2. Ratio of observed to expected number of rheumatoid arthritis, by"education,"cities combined.

education (Fig. 2) shows a lower level for persons with rheumatoid arthritis than for those without it, although the difference was not significant. No consistent difference was observed in women. There is a suggestion that women with rheumatoid arthritis have more education, the number however is very small.

\section{Laboratory data}

Rheumatoid factor. To determine the consistency of the performance of techniques employed in the Hiroshima-Nagasaki group, assays involving the Hyland RA slide test and the F II LP procedure were compared with Ann Arbor. These assays were done in the individual laboratories on predetermined dates. In 64 per cent of the tests the reported titer was the same from the two laboratories; in an additional 10 per cent, the titers were within one tube of each other; if certain 'atypical reactions', are ignored, the agreement was 90 per cent within two tube limits. 
Table 8. Prevalence and distrubution of titer of latex fixation tube test by age and sex, HIROSHIMA

\begin{tabular}{|c|c|c|c|c|c|c|c|c|}
\hline \multirow{2}{*}{ Sex } & \multirow{2}{*}{ Titer } & \multicolumn{7}{|c|}{ Age } \\
\hline & & $<30$ & 30 & $40-$ & $50-$ & 60 & $70+$ & Total \\
\hline \multirow{17}{*}{ Male } & Total & 207 & 686 & 353 & 539 & 605 & 270 & 2660 \\
\hline & Negative & $\begin{array}{c}196 \\
196\end{array}$ & 615 & 323 & 474 & 528 & 233 & 2369 \\
\hline & & & & & & & & \\
\hline & 20 & 1 & 2 & 2 & 6 & 5 & 1 & 17 \\
\hline & 40 & 1 & 3 & 1 & 6 & 3 & 3 & 17 \\
\hline & 80 & 0 & 9 & 4 & 5 & 2 & 5 & 25 \\
\hline & 160 & 1 & 4 & 2 & 5 & 6 & 2 & 20 \\
\hline & 320 & 2 & 11 & 4 & 10 & 13 & 6 & 46 \\
\hline & 640 & 1 & 6 & 1 & 6 & 10 & 6 & 30 \\
\hline & 1280 & 1 & 10 & 7 & 10 & 10 & 2 & 40 \\
\hline & 2560 & 4 & 19 & 5 & 10 & 17 & 6 & 61 \\
\hline & 5120 & 0 & 7 & 4 & 7 & 11 & 6 & 35 \\
\hline & Sub total & 9 & 57 & 23 & 48 & 67 & 28 & 232 \\
\hline & $160+$ & $(4.3 \%)$ & $(8.3 \%)$ & $(6.5 \%)$ & $(8.9 \%)$ & $(11.1 \%)$ & $(10.4 \%)$ & $(8.7 \%)$ \\
\hline & Total & & 1064 & 1152 & 1009 & & 359 & 4846 \\
\hline & Negative & 291 & 961 & 1033 & 896 & 810 & 315 & 4306 \\
\hline & & $(92.7 \%)$ & $(90.3 \%)$ & $(89.7 \%)$ & $(88.8 \%)$ & $(85.4 \%)$ & $(87.7 \%)$ & $(88.9 \%)$ \\
\hline \multirow{11}{*}{ Female } & 20 & 3 & 7 & 8 & 9 & 6 & 2 & 35 \\
\hline & 40 & 4 & 5 & 9 & 5 & 8 & 1 & 32 \\
\hline & 80 & 1 & 13 & 7 & 11 & 9 & 2 & 43 \\
\hline & 160 & 3 & 6 & 16 & 9 & 13 & 2 & 49 \\
\hline & 320 & 1 & 14 & 13 & 18 & 19 & 5 & 70 \\
\hline & 640 & 3 & 12 & 22 & 10 & 25 & 8 & 80 \\
\hline & 1280 & 3 & 21 & 16 & 18 & 26 & 9 & 93 \\
\hline & 2560 & 2 & 15 & 18 & 16 & 15 & 7 & 73 \\
\hline & 5120 & 3 & 10 & 10 & 17 & 17 & 8 & 65 \\
\hline & Sub total & 15 & 78 & 95 & 88 & 115 & 39 & 430 \\
\hline & $160+$ & $(4.8 \%)$ & $(7.3 \%)$ & $(8.2 \%)$ & $(8.7 \%)$ & $(12.1 \%)$ & $(10.9 \%)$ & $(8.9 \%)$ \\
\hline
\end{tabular}

Some technical problems occurred in the latex tube titration test in the Nagasaki laboratory, so the following comments are based on analyses of Hiroshima data alone.

In the Hiroshima sample of 7506 sera, the prevalence of positive latex tube fixation tests, unlike that of clinical rheumatoid arthritis, was found to be equal in males and females (8.7 and 8.9 per cent respectively) and to increase with age in both sexes (Table 8). The distribution of positive cases by titer was similar in both sexes and all age groups.

Of 40 patients with 'definite' rheumatoid arthritis, 30 (75 per cent) had a positive latex fixation tests $(\geqslant 1: 160)$ in Hiroshima. Only 5.2 per cent $(30 / 580)$ of all subjects with positive latex fixation tests were classified as having definite rheumatoid arthritis. The prevalence of positive latex fixation tests $(\geqslant 1: 160)$ in respondents with other diseases is shown in Table 9. A high prevalence of positive latex fixation tests was observed in cirrhosis of the liver, infectious hepatitis and asthma.

To test for possible association of positive latex fixation tests and other clinical and laboratory observations, the mean values of the latter were compared for positive 
Table 9. Prevalence of positive latex fixation tube tests in relation to certain diseases, HIROSHIMA, BOTH SEXES COMBINED

\begin{tabular}{lccccccc}
\hline Disease & ICD No. & \multicolumn{2}{c}{ Disease absent } & & \multicolumn{2}{c}{ Disease present } \\
\cline { 3 - 4 } & & $\begin{array}{c}\text { No. of } \\
\text { persons }\end{array}$ & $\begin{array}{c}\% \text { \% with } \\
\text { positive } \\
\text { LF Test }\end{array}$ & & $\begin{array}{c}\text { No. of } \\
\text { persons }\end{array}$ & $\begin{array}{c}\text { \% with } \\
\text { positive } \\
\text { LF Test }\end{array}$ \\
\hline Pulmonary tuberculosis & $001-008$ & 7363 & 8.7 & & 143 & 14.0 \\
Syphilis & $020-029$ & 7311 & 8.7 & & 195 & 13.8 \\
Infectious hepatitis & 092 & 7501 & 8.8 & & 5 & 40.0 \\
Neoplasm, malignant & $140-205$ & 7396 & 8.7 & & 110 & 14.5 \\
Asthma & 241 & 7473 & 8.8 & & 33 & 24.2 \\
Dabetes mellitus & 260 & 7108 & 8.7 & & 398 & 11.1 \\
Rheumatic heart disease & $410-416$ & 7452 & 8.8 & & 54 & 14.8 \\
Peptic ulcer & $540-541$ & 7396 & 8.8 & & 110 & 9.1 \\
Liver cirrhosis & 581 & 7386 & 8.5 & & 120 & 26.7 \\
Osteoarthritis & 723 & 7147 & 8.6 & & 359 & 12.8 \\
\hline
\end{tabular}

$(\geqslant 1: 160)$ and negative reactions by five age groups. The clinical and laboratory observations included: systolic and diastolic blood pressure, serum cholesterol, serum uric acid, blood sugar, mean corpuscular hemoglobin concentration (MCHC), hematocrit, white blood cell count, and serum protein fractions, i.e. albumin, alpha one, alpha two, beta and gamma globulins.

Comparison between latex fixation test positive and negative groups in five age groups werc also madc by distribution according to $\mathrm{ABO}$ blood type, agc-adjusted proportions of individuals with proteinuria, positive Wasserman test and positive cephalin-cholesterol flocculation test (Table $10 \mathrm{a}-\mathrm{h}$ ).

No particular relationship was observed between positive or negative latex tube fixation tests and the means of serum uric acid, blood sugar, cholesterol and blood pressure values.

The mean of MCHC, white blood cell counts and albumin were consistently lower and the gamma globulin consistently higher for the group with positive latex tube fixation. No difference was observed in $\alpha_{1}, \alpha_{2}$, and $\beta$ globulins in these comparison groups. Positive cephalin-cholesterol flocculation and positive and weakly positive cardiolipin tests were significantly higher in the positive latex tube fixation groups. Distributions of $\mathrm{ABO}$ blood type and proportions with positive proteinuria did not differ for these two comparison groups.

\section{Other laboratory data}

The mean values of serum cholesterol, uric acid, blood sugar, hematocrit and albumin were consistently lower in individuals with definite rheumatoid arthritis than those without arthritis; the mean white blood cell count and gamma globulin content, on the other hand, were consistently higher in those with rheumatoid arthritis in most of the ten age and sex groups, although the difference was not statistically significant in any age or sex group.

No significant difference was observed in the age-adjusted proportion of subjects with positive serological tests for syphilis or in the distribution by $\mathrm{ABO}$ blood type between those with and without rheumatoid arthritis. 


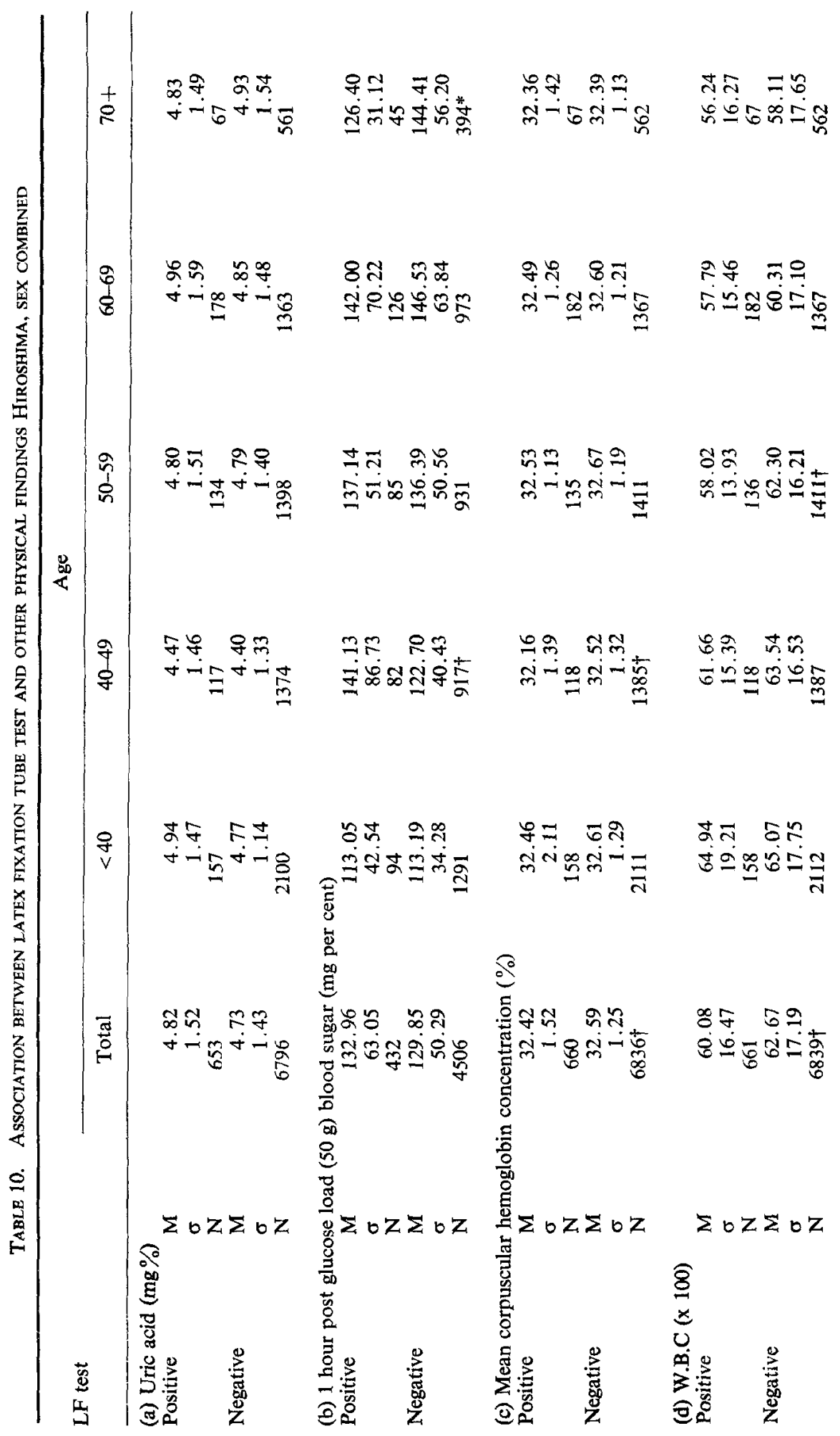




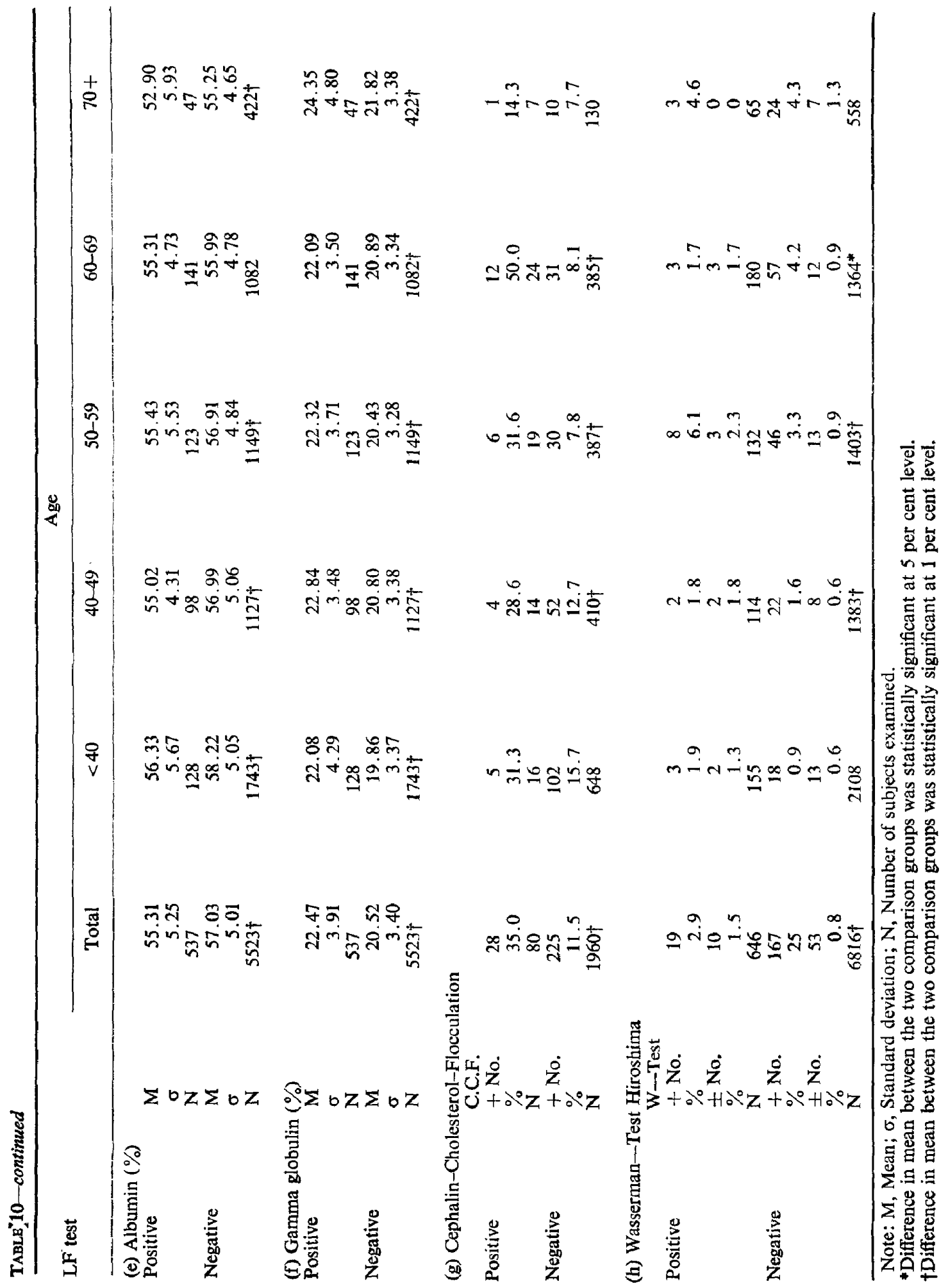




\section{$X$-ray data}

PA roentgenograms of the hands and wrists were obtained for all individuals (1303) who were suspected to have rheumatoid arthritis by screening procedures. Such roentgenograms were obtained in 59 of the 63 individuals with definite rheumatoid arthritis; the other 4 were unable to come to the clinic for examination because of their disease.

By Kellgren's criteria [5] all but two ( 97 per cent) with the clinical diagnosis of definite rheumatoid arthritis had abnormalities in the hands and wrists consistent with

TABLE 11. X-RAY Classification* OF SUBJECTS WITH DEFINITE RHEUMATOID ARTHRITIS HiRoshima AND NAGASAKI COMBINED

\begin{tabular}{|c|c|c|c|c|c|c|c|}
\hline \multirow{2}{*}{ Joint } & \multicolumn{5}{|c|}{ Radiologic grade of rheumatoid arthritis } & \multirow{2}{*}{$\begin{array}{l}\text { Subject } \\
\text { c X-ray }\end{array}$} & \multirow[b]{2}{*}{ Not done } \\
\hline & 0 & 1 & 2 & 3 & 4 & & \\
\hline 1. Hand and wrist & 2 & 6 & 17 & 15 & 19 & 59 & 4 \\
\hline 2. Elbow & 8 & 0 & 9 & 5 & 6 & 28 & 35 \\
\hline 3. Shoulder & 10 & 0 & 1 & 1 & 0 & 12 & 51 \\
\hline 4. Knee & 23 & 10 & 5 & 5 & 1 & 44 & 19 \\
\hline 5. Ankle & 9 & 1 & 0 & 1 & 1 & 12 & 51 \\
\hline 6. Feet & 14 & 1 & 13 & 5 & 3 & 36 & 27 \\
\hline 7. c-Spine & 15 & 2 & 1 & 1 & 0 & 19 & 44 \\
\hline 8. Mandible & 1 & 0 & 1 & 0 & 0 & 2 & 61 \\
\hline
\end{tabular}

*Kellgren, et al [5].

rheumatoid arthritis. A number of these individuals (Table 11) had X-rays of other joints available for study. There was less correlation of radiographic and clinical findings for elbows, feet, knees, ankles, cervical spine and shoulders in that order.

\section{Distribution characteristics of serum uric acid}

To evaluate comparability between laboratories, serum uric acids were determined for samples in both Hiroshima and Ann Arbor, using the same automated procedure. These samples were obtained from patients with gout known to have hyperuricemia, and from individuals with rheumatic and non-rheumatic diseases. The mean values were 3.9 and $4.1 \mathrm{mg} / 100 \mathrm{ml}$ in Hiroshima and Ann Arbor respectively. Eleven per cent of the values were identical; 84 per cent were within $0.3 \mathrm{mg} / 100 \mathrm{ml}$; in only one sample was the discrepancy greater than $1.0 \mathrm{mg}$ per $100 \mathrm{ml}$.

The sex specific mean uric acid values for all age groups is presented in Table 12.

Table 12. SeX specific mean uRIC acid Values of Residents of Hiroshima, NaGasaki, JaPan, COMYARED WITH THOSE OF TeCUMSEH, MichigaN, 1960

\begin{tabular}{|c|c|c|c|c|c|c|c|}
\hline \multirow{3}{*}{$\begin{array}{l}\text { Locale } \\
\text { Hiroshima } \\
(1965-1966)\end{array}$} & \multirow{3}{*}{$\begin{array}{c}\begin{array}{c}\text { Ethnic* } \\
\text { group }\end{array} \\
\text { Japanese }\end{array}$} & \multicolumn{3}{|c|}{ Males } & \multicolumn{3}{|c|}{ Females } \\
\hline & & \multirow{2}{*}{$\begin{array}{c}\begin{array}{c}\text { No. of } \\
\text { subjects }\end{array} \\
2636\end{array}$} & \multicolumn{2}{|c|}{$\begin{array}{c}\text { UA (AC) } \\
\text { in mg/100 ml } \\
\text { Mean S.D. }\end{array}$} & \multirow{2}{*}{$\begin{array}{c}\begin{array}{c}\text { No. of } \\
\text { subjects }\end{array} \\
4813\end{array}$} & \multicolumn{2}{|c|}{$\begin{array}{c}\text { UA (AC) } \\
\text { in } \mathrm{mg} / 100 \mathrm{ml} \\
\text { Mean S.D. }\end{array}$} \\
\hline & & & 5.67 & 1.45 & & 4.23 & 1.14 \\
\hline $\begin{array}{l}\text { Nagasaki } \\
(1965-1966)\end{array}$ & Japanese & 1305 & 5.50 & 1.39 & 1914 & 4.07 & 1.02 \\
\hline $\begin{array}{l}\text { Tecumseh } \\
\text { (1962-1965) }\end{array}$ & Caucasian & 1378 & 5.79 & 1.43 & 1441 & 4.73 & 1.07 \\
\hline
\end{tabular}




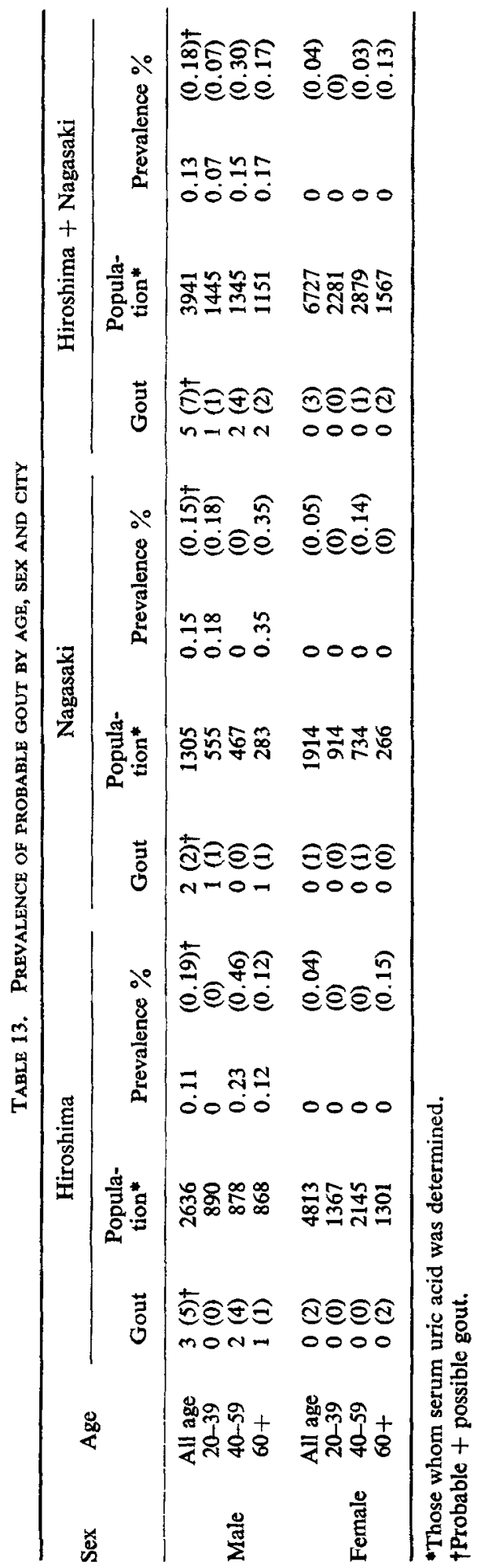


In Tecumseh residents [10] the mean serum uric acid concentration was $5.8 \mathrm{mg}$ per $100 \mathrm{ml}$ for males and $4.7 \mathrm{mg}$ for females; in residents of Hiroshima, the values were, respectively, 5.6 and $4.2 \mathrm{mg}$ per $100 \mathrm{ml}$.

\section{Prevalence rates for gout}

As far as possible, the diagnosis of 'probable gout' was based on criteria recommended for epidemiological studies [11]. As shown in Table 13, among 7499 Hiroshima residents who had serum uric determinations, three males had 'probable gout', a prevalence rate of 0.11 per cent. Gout was not found among females. In 3219 Nagasaki individuals, there were two males and no females with this diagnosis. In the Tecumseh experience the overall prevalence of 'probable gout' for subjects aged 20 and over was 0.5 per cent in males and 0.3 per cent in females. These rates are significantly higher than those in Hiroshima and Nagasaki.

\section{DISCUSSION}

\section{Prevalence and incidence of rheumatoid arthritis}

Prevalence of 'definite' rheumatoid arthritis reported for various populations whose diagnoses are based on criteria of the American Rheumatism Association is shown elsewhere [2]. Difference in methodology and interobserver variability make comparisons of results difficult; common diagnostic criteria reduce but do not completely eliminate difficulties in comparison. In several of the reported studies only subjects who were suspected of having the disease were actually examined. Direct comparison of data is further complicated by variations from one study to another in the age and sex distribution of samples.

The present study is one of the largest existing. The youngest member of the sample was 20 years of age. All subjects were examined. Methods of examination were similar to those of the Tecumseh project. Age adjusted prevalence rates for definite rheumatoid arthritis in Hiroshima and Nagasaki females were significantly lower than those in Tecumseh, but such differences were not observed in males. Age and sex specific prevalence figures for the two Japanese cities are also slightly lower

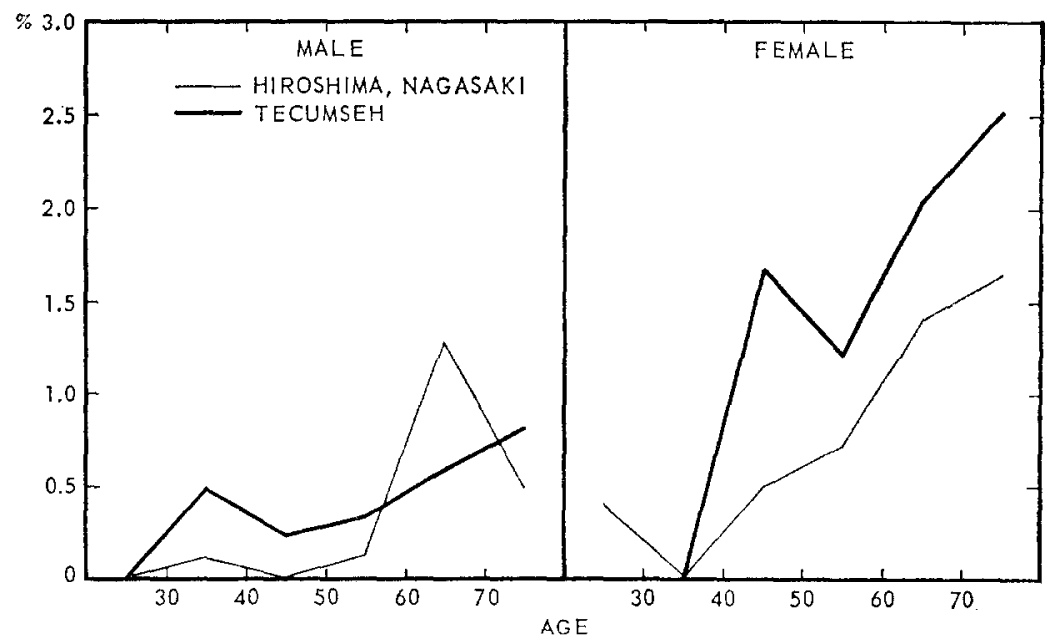

FIG. 3. Prevalence of definite rheumatoid arthritis by age and sex, in Hiroshima, Nagasaki and Tecumseh. 
than in Tecumseh, as shown in Fig. 3, though the difference is not statistically significant except for female ages $40-49$.

\begin{tabular}{|c|c|c|c|c|c|c|c|}
\hline \multicolumn{4}{|c|}{$\begin{array}{c}\text { Hiroshima + Nagasaki } \\
1965-1966\end{array}$} & \multirow{3}{*}{$\begin{array}{c}\text { No. } \\
\text { Examined } \\
(20 \mathrm{yr}+)\end{array}$} & \multirow{2}{*}{\multicolumn{3}{|c|}{$\begin{array}{l}\begin{array}{l}\text { Tecumseh } \\
1958-1960\end{array} \\
\text { Prevalence }\end{array}$}} \\
\hline \multirow{2}{*}{$\begin{array}{c}\text { No. } \\
\text { Examined } \\
(20 \mathrm{yr}+)\end{array}$} & \multicolumn{3}{|c|}{ Prevalence } & & & & \\
\hline & $\mathbf{M}$ & $F$ & $\mathrm{~T}$ & & $\mathbf{M}$ & $F$ & $\mathrm{~T}$ \\
\hline 11,393 & 0.38 & 0.65 & 0.55 & 4618 & $\begin{array}{l}0.31 \\
0.40^{*}\end{array}$ & $\begin{array}{l}0.78 \\
1.15^{*}\end{array}$ & $\begin{array}{l}0.56 \\
0.78^{*}\end{array}$ \\
\hline
\end{tabular}

*Age adjusted prevalence rate using Hiroshima and Nagasaki population as standard.

Two other Japanese studies with large samples have been reported; one in Shizuoka Prefecture [12], the other in Osaka City [13]. Each was based on nearly 3000 subjects and provided prevalence for definitc rheumatoid arthritis of 0.2 and 0.8 per cent respectively, all ages combined.

Comparisons of prevalence rates of definite rheumatoid arthritis in our sample for the periods 1959-1964 and 1965-1966 follow:

TOTAL PREVALENCE OF DEFINITE RHEUMATOID ARTHRITIS

\begin{tabular}{lccccccc}
\hline & \multicolumn{3}{c}{$1958-1964$} & & \multicolumn{3}{c}{$1965-1966$} \\
\cline { 3 - 4 } \cline { 6 - 7 } & Hiroshima & Nagasaki & Total & Hiroshima & Nagasaki & Total \\
\hline M & 0.22 & 0.14 & 0.20 & 0.47 & 0.21 & 0.38 \\
F & 0.49 & 0.35 & 0.45 & 0.62 & 0.72 & 0.65 \\
T & 0.39 & 0.26 & 0.35 & 0.57 & 0.52 & 0.55 \\
\hline
\end{tabular}

The prevalence rate was higher for the recent period, and this was true when examined by age and sex. Explanation for these differences are possibly reflective of differences in methods of detection, inasmuch as the 1958-1964 observations were based on routine physical examinations while the present study was designed specifically to detect rheumatoid arthritis, using additional diagnostic criterion (X-rays and rheumatoid factor tests). It is possible that suspected cases may have progressed to the definite category and hence appear in the present study.

Prior to this report, little data was available concerning incidence of rheumatoid arthritis. A rough estimate of 0.05 per cent per year was based on observations of this sample from 1958 to 1964 [2]. In the present study, all persons who developed definite rheumatoid arthritis since previous examinations in the 1958-1964 period were identified. Incidence rates per year were 0.07 per cent for males and 0.11 per cent for females.

INCIDEIVCE PER YEAR OF DEFINTTE RHEUMATOID ARTHRITIS IN HIROSHIMA AIND NAGASAKI

\begin{tabular}{lcc}
\hline & $\begin{array}{c}1958-1964 \text { Study } \\
(\%)\end{array}$ & $\begin{array}{c}1965-1966 \text { Study } \\
(\%)\end{array}$ \\
\hline M & 0.019 & 0.069 \\
Total & 0.063 & 0.114 \\
\hline
\end{tabular}


The prevalence of rheumatic complaints in this population is remarkably lower than those in Tecumseh population as shown in Table 5. The prevalence of morning stiffness in Hiroshima were 8.8 and 13.5 per cent for male and female respectively, while the corresponding age adjusted rates were 24.5 and 31.0 per cent for male and female respectively in Tecumseh.

Positive replies to questions 1,3 and 4 composed a positive 'rheumatoid arthritis index', as defined by Cobb et al $[8,9]$. It is of considerable interest to see how this index served its intended purpose as a 'screen' for the detection of rheumatoid arthritis. Of the 10,703 subjects with a negative 'index' 10,690 ( 99.9 per cent) did not have definite rheumatoid arthritis. Thus, it would appear that this index did serve a valuable purpose in that definite rheumatoid arthritis was extremely rarely detected among subjects with a negative index. On the other hand, of the total 61 definite rheumatoid arthritis cases, 13 subjects $(22.3$ per cent) were found to have a negative index. This suggests it would have been unwise to rely exclusively on a positive rheumatoid arthritis index for case identification, since a significant portion of cases of rheumatoid arthritis would thereby be missed.

\section{Latex fixation test for detection of the rheumatoid factor}

Unlike clinical rheumatoid arthritis, the prevalence of positive latex fixation tests was found equally among males and females and it increased with age in both sexes, similar to observations in the Tecumseh Study [3] (Fig. 4). Prevalence rates for

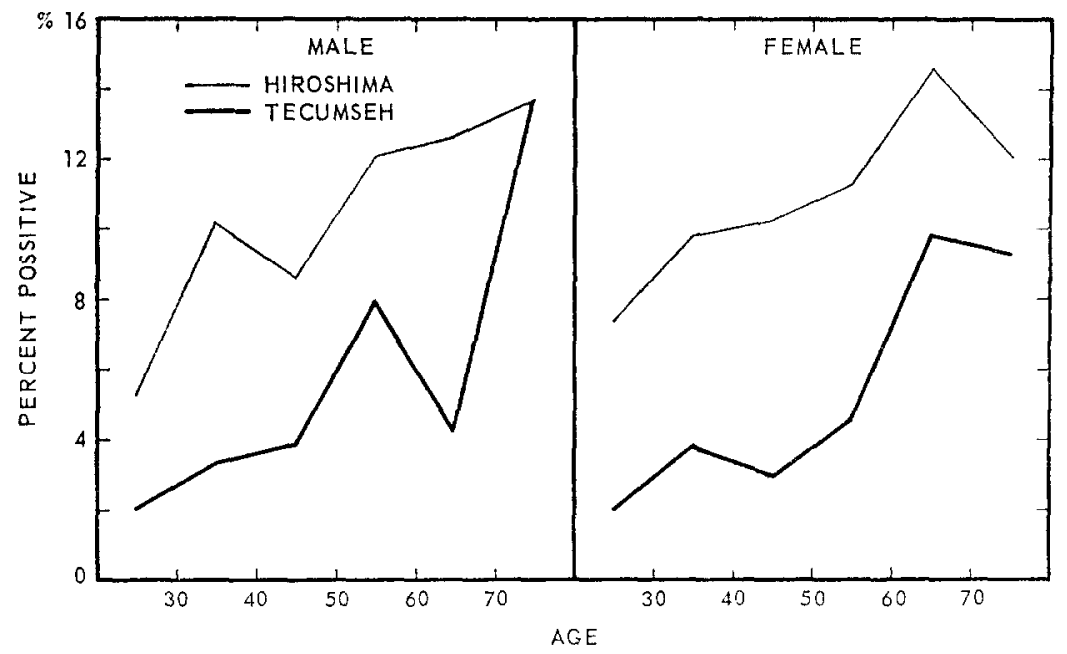

FIG. 4. Prevalence of positive rheumatoid factor (LF test) by age and sex in Hiroshima and Tecumseh.

positive latex fixation tests in each age group are, however, consistently two or three times higher in Hiroshima than in Tecumseh, though the prevalence of definite rheumatoid arthritis is slightly lower in Hiroshima than in Tecumseh. Since the consistency check of technical aspects of the latex fixation tests showed good agreement between Hiroshima and Tecumseh, the observed differences are unlikely to be technical in origin. Significant differences in known and unknown environmental factors may be the explanation. Also, since the prevalence of positive latex fixation is reported to be higher in urban than rural arcas [14], the difference may be a reflection of urban 
Hiroshima and rural Tecumseh. Differences in prevalence of other diseases associated with positive latex fixation tests such as liver disease and asthma, could likewise be responsible. The prevalence of positive latex fixation tests in Hiroshima is nearly the same as for an urban area near Osaka [13].

Of 40 patients with 'definite' rheumatoid arthritis, 30 ( 75 per cent) had positive latex fixation tests in Hiroshima. In this study the diagnosis of definite rheumatoid arthritis was made depending more heavily upon the results of latex fixation test and X-rays than in most of other population surveys, since both were used as a 'screen' for detecting rheumatoid arthritis. This fact probably explains the much higher frequency of positive latex fixation tests and abnormal X-rays in these rheumatoid arthritis patients than those in other population studies.

\section{Environmental factors}

With this very small number (63) of definite rheumatoid arthritis cases, definite relationship of the disease to environmental factors could not be demonstrated. Tendencies observed should be regarded as suggestive, rather than definite.

Education. As in the U.S.A. nation-wide Health Examination Survey [15] the prevalence of rheumatoid arthritis was higher in men with a lower level of education. No similar tendency was observed in women.

Occupation. Though prevalence of rheumatoid arthritis was lower than expected for men in managerial and technical positions and professions in the U.S.A. Health Examination Survey [15] and DeGraff's study [16], no such tendency was observed in the present study.

Marital status and number of children. The U.S.A. Health Examination Survey [15] reported significantly less than expected rheumatoid arthritis in widowed men and unmarried women. In addition, and contrary to Cobb's finding [9], the prevalence rate for women with four or more children did not exceed that for those who had one to three children. No such tendency was observed in the present study.

Radiation effect. There was no correlation between rheumatoid arthritis and irradiation from the atomic bombs. Radiation is known to induce mutation. There was no excess of rheumatoid arthritis in atomic bomb survivors with estimated median doses of 118 and 238 rad in Hiroshima and Nagasaki respectively for those who were less than $1400 \mathrm{~m}$ from the hypocenter. This fails to support Burch's hypothesis [17] that somatic mutations are necessary to initiate rheumatoid arthritis.

The mean serum uric acid values of Japanese men and women appear to resemble more closely those of Tecumseh, Michigan, than other ethnic or cultural groups in the Orient. They are, for instance, higher than the published [10] values for Chinese of Taiwan; but lower than those for Chinese males of Malaya and Filipinos of Manila. Schichikawa et al [13] have published uric acid values obtained by colorimetric method in a group of Japanese men and women from rural and urban environments, whose mean values are somewhat lower than those reported here.

Reports of gout in the Japanese have appeared in the Western literature. In 1964, 
Schichikawa and Komatsubara [18] concluded that gout, formerly very infrequent in Japan, is becoming as common as in Western countries, abreast of the rapidly changing way of life in Japan. In population studies, however, it is difficult to find significant numbers of individuals with gout. Schichikawa and Komatsubara's population survey of 2500 men and 2519 women of Osaka Prefecture revealed two males with definite gout and an additional man and woman with possible gout [18]. These prevalence rates are similar to ours.

\section{SUMMARY}

Observations of definite rheumatoid arthritis in a fixed population of 11,393 atomic bomb survivors in Hiroshima and Nagasaki for the period April, 1965 through December, 1966, based on a prospective study designed for specific detection of rheumatoid arthritis are reported. Routine complete physical examinations were performed on all persons in the sample. Screening procedures utilized in all subjects included: completion of a questionnaire and performance of 'rheumatoid factor' tests. When indicated by results of clinical and laboratory examinations, PA roentogenograms of the hands and wrists were obtained. A rheumatologist (ID) reviewed the medical records of all individuals in whom there was evidence to suspect rheumatoid arthritis. 1303 of individual patients whose earlier examinations indicated the need, were recalled for clarification, confirmation and classification of their disease. The time of onset of disease was also established.

The prevalence rate of definite rheumatoid arthritis was 0.38 per cent for males and 0.65 per cent for females, over 20 years of age, and 0.55 per cent for both sexes. This prevalence rate for females was significantly lower than the age adjusted rate in a comparable population in Tecumseh, but this was not so for males. The incidence rate of definite rheumatoid arthritis was 0.07 per cent for males and 0.11 per cent for females per year.

In this sample of Japanese, the prevalence rate of positive latex tube fixation tests for the rheumatoid factor was consistently higher than reported for the comparable Tecumseh, Michigan, population. Adequate explanation of this difference is not now available.

The relationship between rheumatoid arthritis or rheumatoid factor and environmental factors such as education, occupation, and other physical findings such as level of serum uric acid and blood pressure was studied.

No relationship was detected between prevalence and incidence of rheumatoid arthritis and exposure to radiation from the atomic bombs.

The age-sex specific mean uric acid values for Japanese men and women were very similar to those in a Caucasian population. In this population survey, as reported in others, very few cases of gout were detected.

Acknowledgements - We express our appreciation to the Adult Health Study subjects of Hiroshima and Nagasaki who by their participation, made this investigation possible. We are indebted to Mr. and Mrs. Scott Himes, of the Rackham Unit, University of Michigan for making the exchange of laboratory specimens and data possible. 


\section{REFERENCES}

1. Hollingsworth JW: Delayed radiation effect in survivors of the atomic bombings: Review of the findings of the Atomic Bomb Casualty Commission, 1947-59. New Eng J Med 263: 481487,1960

2. Wood WJ, Kato H, Johnson KG, et al: Rheumatoid arthritis in Hiroshima and Nagasaki, Japan. Arthritis Rheum 10: 21-31, 1967

3. Mikkelsen WM, Dodge HJ, Duff IF, et al: Estimates of the prevalence of rheumatic disease in the population of Tecumseh, Michigan, 1959-60. J Chron Dis 20: 351-369, 1967

4. Singer JM, Plotz CM: The latex fixation test. 1. Application to the scrologic diagnosis of rheumatoid arthritis. Am J Med 21: 888-892, 1956

5. Kellgren JH, Jeffrey MR, Ball J: Atlas of standard radiographs of arthritis. In The Epidemiology of Chronic Rheumatism. Oxford, Blackwell Scientific Publications, 1963, Vol 2

6. Ropes MW, Bennett GA, Cobb S, et al: 1958 revision of diagnostic criteria for theumatoid arthritis. Bull Rheum Dis 9: 175-176, 1958

7. Milton RC, Shohoji T: Tentative 1965 radiation dose (T65D) estimation for atomic bomb survivors, Hiroshima-Nagasaki. ABCC Technical Report, 1968

8. Rubin T, Rosenbaum J, Cobb S: The use of interview data for the detection of associations in field studies. J Chron Dis 4: 253-266, 1956

9. King SH, Cobb S: Psychosocial factors in the epidemiology of rheumatoid arthritis. J Chron Dis 7: 466-475, 1958

10. Duff IF, Mikkelsen WM, Dodge HJ, et al: Comparison of uric acid levels in some Oriental and Caucasian groups unselected as to gout or hyperuricemia. Arthritis Rheum 11: 184-190, 1968

11. Kellgren JH, Jeffrey MR, Ball J (Ed): The Epidemiology of Chronic Rheumatism. Philadelphia, F.A. Davis, 1963, pp 295-297

12. Oshima Y: Clinical findings of collagen disease. 5. Rheumatism. J Jap Soc Intern Med 50: 774-780, 1960

13. Schichikawa K, Mayeda A, Komatsubara $Y$, et al: Rheumatic complaints in urban and rural populations in Osaka. Ann Rheum Dis 25: 25-31, 1966

14. Ball J, Lawrence JS: Epidemiology of the sheep cell agglutination test. Ann Rheum Dis 20: 235-243, 1961

15. Engel A, Roberts J, Burch TA: Rheumatoid arthritis in adults in the United States 1960-1962. Vital and Health Statistics. Series 11, Data from the National Health Survey. Number 17, Washington DC, National Center for Health Statistics, 1966

16. De Graaff $R$ : Rheumatoid arthritis in the Netherlands. Its prevalence and social aspects. Proceedings of the ISRA symposium on the social aspects of chronic rheumatism joint affection s especially rheumatoid arthritis. International Congress Series No 23. New Yosk, Excerpta Medica Foundation, 1959, pp 7-14

17. Burch PRJ: Autoimmunity, some aetiological aspects. Lancet i: 1253-1257, 1963

18. Schichikawa K, Komatsubara Y: Gout in Japan. Rev Rheum: 13-16, Jan-Feb, 1964 